$R$ v. Daniels: Issues of Jurisdiction, Identity, and Practical Utility

\author{
Catherine Bell
}

Faculty of Law, University of Alberta

aboriginal policy studies Vol. 3, no. 3, 2014, pp. 132-149

This article can be found at:

http://ejournals.library.ualberta.ca/index.php/aps/article/view/22228

ISSN: $1923-3299$

Article DOI: http://dx.doi.org/10.5663/aps.v3i3.22228

aboriginal policy studies is an online, peer-reviewed and multidisciplinary journal that publishes original, scholarly, and policy-relevant research on issues relevant to Métis, non-status Indians and urban Aboriginal people in Canada. For more information, please contact us at apsjournal@ualberta.ca or visit our website at www.ualberta.ca/nativestudies/aps/.

UNIVERSITY OF ALBERTA

FACULTY OF NATIVE STUDIES
Aboriginal Affairs and

Northern Development Canada

Affaires autochtones et Développement du Nord Canada 


\title{
R v. Daniels: Issues of Jurisdiction, Identity, and Practical Utility
}

\author{
Catherine Bell \\ Faculty of Law, University of Alberta
}

In April 2013, the Federal Court of Appeal (FCA) confirmed in Daniels ${ }^{1}$ that Métis and non-status Indians are included in federal constitutional jurisdiction for "Indians and lands reserved for Indians" under s. 91(24) of the Constitution Act, 1867. ${ }^{2}$ The decision is a victory for non-status Indians and Métis people, because the federal government can no longer use "lack of jurisdiction" alone to deny them access to federal programs and services available to status Indians, or avoid negotiating claims derived from loss or denial of federal Indian status, Métis Aboriginal rights, or socioeconomic needs. However, the decision does not say that Métis and non-status Indians have the same legal rights as other Aboriginal people under federal jurisdiction, nor does it compel the federal government to enact legislation for their benefit or negotiate land or other unfulfilled constitutional obligations. These obligations have to be determined on a case-by-case basis for non-status Indians because the reasons for excluding individuals or groups from status and federal programs are "complex, far ranging and often unrelated to one another."3 Nevertheless, read together with other cases on Métis constitutional rights, practical implications flowing from Daniels may include federal constitutional obligations to: (1) participate in negotiation of claims arising from credibly asserted Métis Aboriginal rights or breaches of constitutional or other historical solemn promises to Métis aimed at reconciling "Métis Aboriginal interests ... with the assertion of Crown sovereignty"; 4 and (2) extend some programs and services to them, particularly those aimed at reconciliation, such as comprehensive treaty negotiation processes.

Despite these implications, since commencement of the litigation in 1999, the federal government has maintained that a declaration stating that Métis and non-status Indians are under federal jurisdiction has no practical utility because it does not create enforceable

1 Daniels v Canada (Minister of Indian Affairs and Northern Development) 2014 FCA 101, [2014] FCJ No 383 [Daniels]. Part of this case comment is drawn from a paper that elaborates the impact of Daniels and $M M F$, infra note 4, on intergovernmental relations and legislative jurisdiction prepared by the author for the State of the Federation: Aboriginal Multilevel Governance conference hosted by the Queen's Institute of Intergovernmental Relations, 28-29 November 2013, and forthcoming in a collection of essays published by McGill-Queen’s Press, 2014.

2 Constitution Act, 1867 (UK), 30 \& 31 Vict, c 3, reprinted in RSC 1985, App II, No 5.

3 Daniels, supra note 1 at para. 77.

4 Manitoba Metis Federation Inc. v Canada (Attorney General), 2013 SCC 14 at para. 9, [2013] 1 S.C.R. 263 $[M M F]$.

aboriginal policy studies, vol. 3, no. 3, 2014

www.ualberta.ca/nativestudies/aps/

ISSN: $1923-3299$ 
legal obligations on the part of the federal government. On appeal, the federal government argued that Justice Phelan of the Federal Court Trial Division (FCTD) erred in law for this reason, and in "adopting a definition of Métis that is contrary to history and the jurisprudence of the Supreme Court; failing to follow the proper approach to constitutional analysis mandated by the Supreme Court; and granting a declaration that will create uncertainty about the jurisdiction of Parliament and the provincial legislatures"5 - the last argument centering on Alberta’s Métis settlement legislation and its potential vulnerability to constitutional challenge if federal jurisdiction over Métis is upheld.

The following case comment examines why Justice Phelan declared that non-status Indians and Métis are under federal jurisdiction, the issues appealed to the FCA, why the FCA held that a declaration on constitutional jurisdiction has practical utility for the Métis but is "redundant" for non-status Indians, ${ }^{6}$ and some of the possible implications of the ruling, with particular emphasis on the practical utility of Daniels for Métis. On June 16, 2014 the Congress of Aboriginal People (CAP) filed leave to appeal to the Supreme Court of Canada on the grounds that the FCA erred in excluding non-status Indians from the scope of the declaration and for failing to grant an ancillary declaration that the federal Crown has an obligation to negotiate and consult with the Métis and non-status Indians.

\section{The Issues on Trial}

Daniels is about much more than constitutional interpretation and jurisdiction. It is fundamentally about discrimination arising from Indian policy that "divided families and communities according to externally created categories, and destabilized social structures necessary for communities to function." ${ }^{7}$ Federal policy did not anticipate that those who lost status would coalesce as a group for political or other purposes, but rather that they, and the Métis, would assimilate into the broader Canadian society. Daniels is also about denial of the existence of Métis as a distinct Aboriginal people with Aboriginal constitutional rights. Leading up to and since recognition of Aboriginal constitutional rights in s. 35 of the Constitution Act, 1982, the federal government has interpreted its s. 91(24) jurisdiction to exclude non-status Indians and Métis who live south of the 60th parallel. This has not always been the case; rather, Métis were "both included and excluded from recognized Indian status in accordance with changing government policies."

Evidence at trial directed at the term "Indian" demonstrated that it was understood at the time of Confederation to include "'half-breeds,' and one did not have to live on a

5 Daniels, supra note 1 at para 81.

6 Ibid. at para 76.

7 Betty Ann Lavallée, “The Daniels Case: Recognition of Métis and Non-Status Aboriginal Peoples,” speech delivered at the Ottawa Marriot Hotel, 20 June 2013, available from http://www.abo-peoples.org/nationalchief-betty-ann-lavallee-speech-on-the-daniels-case-recognition-of-metis-and-non-status-aboriginalpeoples/.

8 Daniels, supra note 1 at para. 51. 
reserve or in an Indian community to be an 'Indian."' 9 The framers of the Constitution intended the word "and the power that went with it, to be a broad power capable of dealing with the diversity and complexity of the native population, whatever their percentage of mix of blood relationship, their economies, residency or culture" including "recognition, control and dealing with Metis who were seen as distinct in some respects from 'Indians."'10 Following Confederation, part of creating an "environment of safety and security for settlers" was the extinguishment of Indian and Métis claims. ${ }^{11}$ The federal government exercised jurisdiction over Métis using "Indian power like methods" to further these objectives $^{12}$ including through legislated prohibition of sales of liquor to Métis, distribution of individual scrip exchangeable for land or money, treaty negotiation, and the creation of "half-breed reserves" such as St. Paul-de-Métis. ${ }^{13}$

Concern about "financial consequences of recognizing this jurisdiction" after Métis inclusion in s. 35 of the Constitution Act, $1982^{14}$ resulted in a shift in federal policy. ${ }^{15}$ Since then, provinces have undertaken some Métis initiatives invoking jurisdiction under s. 92 of the Constitution Act, 1867 (e.g., property and civil rights). However, they deny jurisdiction to negotiate Métis Aboriginal rights claims and, with a few notable exceptions, have refused to negotiate or implement through legislation land and governance agreements with the Métis. ${ }^{16}$ Since the recognition of Métis Aboriginal rights to hunt, fish, gather, and trap for food by the SCC in $R v$ Powley, some provinces have also negotiated agreements and amended provincial laws to accommodate these rights in some geographical regions. ${ }^{17}$ However, the scope of these rights and the Métis people entitled to exercise them continue to be debated and litigated. ${ }^{18}$

Federal and provincial governments also deny that Métis people have Aboriginal title or other Aboriginal land interests south of the $60^{\text {th }}$ parallel. They maintain that if such rights existed as Aboriginal rights at common law, they were terminated prior to their constitutional protection in 1982 through scrip distribution to Métis living largely in

9 Ibid. at para. 31.

10 Ibid. at para. 31.

11 Ibid. at para. 38.

12 Ibid. at para. 40.

13 Ibid. at paras. $38-51$.

14 Constitution Act, 1982, being Schedule B to the Canada Act 1982 (UK), 1982, c 11.

15 Daniels v Canada (Minister of Indian Affairs and Northern Development) 2013 FCJ 6 at para. 501, [2013] FCJ No 4 [Daniels FC].

16 See e.g. Métis Act, SS 2001, c M-14.01; Métis Settlements Act, RSA 2000, c M-14.

17 R v Powley 2003 SCC 43, [2003] 2 SCR 207 [Powley].

18 See e.g. $R v$ Hirsekorn 2013 ABCA 242, 556 AR 53. 
what are now the Northwest Territories, Manitoba, Alberta, and Saskatchewan. ${ }^{19}$ A recent decision by the SCC, Manitoba Metis Federation Inc. v. Canada (Attorney General) (MMF), is important because it says, "No - this assumption is wrong." 20 The federal Crown failed to implement the land grant provision to Métis contained in s. 31 of the Manitoba Act, 1870 in a manner consistent with the honourable standards demanded of the Crown in its dealings with Aboriginal people. ${ }^{21}$ As a consequence, legal obligations to Métis under s. 31 remain "largely unfulfilled," and its broader purpose to "reconcile the Métis Aboriginal interests in the Manitoba territory with the assertion of Crown sovereignty" has not been achieved. ${ }^{22}$ As elaborated below, to understand the practical implications of Daniels, it must now be read together with this decision.

This history, lack of jurisdictional clarity, and "political policy wrangling" between the federal and provincial governments has produced what Justice Phelan describes as "a large population of collaterally damaged" people ${ }^{23}$ and exposed Métis and non-status Indians to discrimination and suffering as the most disadvantaged Aboriginal people in Canada. ${ }^{24}$ Other ramifications continue to include: (1) inability to access "programs, services and intangible benefits recognized by all governments as needed"; ${ }^{25}$ (2) federal reluctance to negotiate or develop national initiatives or socioeconomic programs aimed at the impact of colonization on Métis Aboriginal rights and the Métis as an Aboriginal people; (3) differential provincial treatment; and (4) exclusion from federal programs and negotiation processes designed to address Aboriginal land claims. It is also this experience and the death of the Charlottetown Accord ${ }^{26}$ (which would have clarified that s. 91[24] included Métis in a national referendum in 1992) that ultimately led Harry Daniels, the Congress of Aboriginal Peoples (CAP), and Leah Gardiner, a non-status Indian from Wabigoon, Ontario, to launch the case against Canada. They asked the Federal Court to grant three declarations: ${ }^{27}$

19 See Dominion Lands Act, 1879, SC 1879, c 31, s 125(e); Dominion Lands Act, 1883, SC 1883, c 17, ss 81(e), 83; Manitoba Act, 1870 RSC 1985, App II, No 8, s 31 [Manitoba Act].

20 MMF, supra note 4. For a comment on this case see Darren O’Toole, "Case Commentary: Manitoba Metis Federation v. Canada and Manitoba,” Aboriginal Policy Studies 3 (2014), 178.

$21 M M F$, ibid. at paras. 9, 110.

22 Ibid. at para. 9.

23 Daniels FC, supra note 15 at para. 108.

24 Ibid. at paras. 26,84 .

25 Ibid. at para. 108.

26 Charlottetown Accord: Draft Legal Text (Supply and Services Canada, 1992).

27 Daniels FC, supra note 15 at para. 3. 
(a) that Métis and non-status Indians are "Indians" within the meaning of the expression "Indians and lands reserved for Indians" in s 91(24) of the Constitution Act, 1867;

(b) that the Queen (in right of Canada) owes a fiduciary duty to Métis and nonstatus Indians as Aboriginal people;

(c) that the Métis and non-status Indian peoples of Canada have the right to be consulted and negotiated with, in good faith, by the federal government on a collective basis through representatives of their choice, respecting all their rights, interests and needs as Aboriginal peoples.

Justice Phelan granted the first declaration. He also held that a fiduciary relationship exists between the federal government and the Métis "as a matter of law flowing from the declaration," and that this relationship "engages the honour of the Crown." 28 He agreed in theory that Canada may have enforceable fiduciary obligations toward, and a duty to consult and negotiate in good faith with, Métis. However, these issues cannot be resolved in the abstract, only within a specific factual context and in relation to a specific interest. Nevertheless, in his opinion, to the extent that lack of jurisdictional clarity operated as a barrier to consultation and negotiation, a declaration should remove this impediment. ${ }^{29}$

In reaching this conclusion, Justice Phelan adopted a purposive approach to constitutional interpretation (referred to as the "living tree doctrine") and rejected the argument that matters falling under s. 91(24) are restricted by the original historical intent of the framers of the Constitution. In R. v. Blais (2003), the SCC directed analysis of constitutional provisions be "anchored in historical context," and held that the purpose of paragraph 13 of The Manitoba Natural Resources Transfer Act ${ }^{30}$ to protect and assist Indians was inconsistent with including Manitoba Métis in the definition of "Indians" under that paragraph. ${ }^{31}$ Because the Métis of the Red River identified as a distinct people, claimed a different political status, and were "its negotiating partners in the entry of Manitoba into Confederation," the Crown viewed its obligations to Métis as different from those it had to Indians, whom it considered its wards. ${ }^{32}$ However, a year later, in Reference re Same-Sex Marriage (2004) (Re Same-Sex), the SCC confined this interpretive approach to negotiated "constitutional agreements" and distinguished it from cases, such as Daniels, concerning jurisdictional heads of power, which require "a purposive, progressive approach." 33 Justice Phelan reasoned:

28 Ibid. at para. 607.

29 Ibid. at para. 609.

30 The Manitoba Natural Resources Transfer Act, CCSM c N30.

$31 R v$ Blais, 2003 SCC 44 at para. 17, [2003] 2 SCR 236 [Blais].

32 Ibid. at para. 33.

33 Reference re Same-Sex Marriage, 2004 SCC 79, [2004] 3 SCR 698 as cited in Daniels FC, supra note 15 at paras. 538-539. 
$[\mathrm{T}]$ he "living tree" doctrine ... is the appropriate approach. History helps to understand perspectives on the purpose but does not necessarily determine the purpose for all time. This is particularly the case with a constitution power which has, at some level, racial tones and which involved people who were seen in a light which today we would find offensive. Racial stereotyping is not a proper basis for constitutional interpretation.

The Defendants' argument that the purpose of s 91(24) was to allow the federal government the power to protect Indians and their lands because Indians were viewed as childlike uncivilized people (the Defendants were clear that it did not endorse that view of the natives) ignores the far broader and more acceptable purposes for the s 91(24) power. These include the acceptance of the Crown's responsibilities to natives, obligations under the Royal Proclamation of 1763, the need for coordinated approach to natives rather than the balkanized colonial regimes and the need to deal with the rapid and forcible expansion into the West including Euro-Canadian settlement and the building of the national railway. ${ }^{34}$

Relying on historical evidence and a 1976 decision of the SCC, Canada v. Canard, ${ }^{35}$ Justice Phelan explained that the original objectives of s. 91(24) were race-based ${ }^{36}$ and that non-status and Métis were considered part of the racial classification of "Indians" through intermarriage and descent. ${ }^{37} \mathrm{He}$ defined non-status Indians as having "two essential qualities by definition: they have no status under the Indian Act and they are Indians." ${ }^{38} \mathrm{He}$ also said that for the purpose of s.91(24), "the single most distinguishing feature of non-status and Métis is that of 'Indianness', not language, religion or connection to European heritage." ${ }^{39}$ They were best described as "a group of native people who maintained a strong affinity for their Indian heritage without possessing Indian status. Their 'Indianness' was based on selfidentification and group recognition." ${ }^{40}$ At the same time, Justice Phelan recognized that Métis are a distinct Aboriginal people, but reasoned that, as with the Inuit, recognition of their distinctiveness as a people under s. 35 of the Constitution Act, 1982 does not exclude them from federal jurisdiction over "Indians" under s. 91(24) of the Constitution Act, 1867. Section 35 is aimed at protecting rights integral to and enhancing the survival of distinct cultures of distinct peoples requiring, of necessity, identification with First Nations, Inuit, or Métis, to the exclusion of the other two.

34 Daniels FC, supra note 15 at paras. 538-539.

35 Attorney General of Canada et al v Canard [1976] 1 SCR 170.

36 Daniels FC, supra note 15 at para. 568.

37 Ibid. at para. 531.

38 Ibid. at para. 116.

39 Ibid. at para. 532.

40 Ibid. at para. 117. 


\section{Issues on Appeal}

The questions on appeal to the FCA were whether Justice Phelan erred in issuing the declaration that Métis and non-status Indians are under s. 91(24) because such a declaration lacks practical utility, whether he erred in fact and law in his analysis and application of s. 91 (24) to the Métis, and whether he erred in failing to order the second and third declarations concerning fiduciary duty, consultation, and negotiation. The FCA upheld his reasons (elaborated above) for refusing the second and third declarations. It also upheld the declaration that Métis are within s. 91(24) jurisdiction. However, it held that Justice Phelan erred in issuing a declaration with respect to non-status Indians, as such a declaration is "redundant and lacks practical utility." 41

Issues of Practical Utility

Several arguments were raised by the federal government against granting the declaration, including assertions that (1) declarations on matters of constitutional jurisdiction should only be granted when the validity of actual or proposed federal or provincial legislation is being challenged; (2) the declaration lacks practical utility because it doesn't compel legal obligations and address the more fundamental issues of exclusion from federal programs and services at the core of the litigation; and (3) the federal government can extend programs and resources to Métis and non-status Indians without constitutional jurisdiction regardless, by using its spending power. ${ }^{42}$ The FCA rejected the first argument on the basis that $M M F$, decided shortly after the trial decision in Daniels, is clear that a declaration can be issued in aid of "extra-judicial negotiations with the Crown in pursuit of the overarching constitutional goal of reconciliation." ${ }^{43}$ However, the issue of practical utility is more complex. To obtain declaratory relief, one of the criteria is that the "question before the Court [be] real and not theoretical." ${ }^{44}$ Here the FCA draws a distinction between discretion to use federal spending power and actually exercising that discretion, ultimately deciding that the question of jurisdiction is "real" for the Métis and has practical consequences, especially given the role jurisdictional debate has played in avoiding negotiation and reconciliation of Métis Aboriginal interests. Potential practical consequences also become more apparent when Daniels is read together with other decisions of the SCC on Métis constitutional rights, in particular MMF, Powley, and Cunningham. ${ }^{45}$

41 Daniels, supra note 1 at para. 76.

42 Ibid. at para. 65.

$43 \mathrm{MMF}$ supra note 4 at para. 137.

44 Daniels, supra note 1 at para. 64, citing Canada (Prime Minister) v. Khadr, 2010 SCC 3 at para. 46, [2010] 1 S.C.R. 44.

45 Alberta (Aboriginal Affairs and Northern Development) v Cunningham, 2011 SCC 37, [2011] 2 SCR 670. 


\section{(1) Non-status}

During oral argument, the federal government conceded that, by definition, non-status Indians are in s. 91(24) because "unlike Metis, who are a distinct people, it is common ground non-status Indians are, broadly speaking, Indians without status under the Indian Act," and thus also First Nations people "to whom status could be granted under federal Indian legislation." ${ }^{46}$ Speaking for the FCA, Justice Dawson elaborated that Parliament gets its authority to grant or withhold Indian status under s. 91(24); to be granted status, a person must be a s. 91(24) Indian, and consequently the Indian Act, ${ }^{47}$ created using this head of constitutional power, does not "exhaustively define who is an Indian for the purpose of the division of powers" or the outer limits of federal jurisdiction. ${ }^{48}$ The latter point is also demonstrated in the circumstances of the Inuit, who are under federal jurisdiction but excluded from status under the federal Indian Act. ${ }^{49} \mathrm{~A}$ declaration that non-status Indians are also s. 91(24) Indians is redundant, as it is stating the obvious.

Further, the FCA held that it would not be possible or appropriate to try to define nonstatus as a group for inclusion in s. 91(24) because the reason for and validity of exclusion for each class of individuals or groups from the Indian Act had to be determined on a "caseby-case basis." ${ }^{0}$ There are many reasons for exclusion from Indian status and programs, including errors in record keeping, being missed in the treaty process, and involuntary loss of status through land surrender, marriage, or employment. ${ }^{51}$ As a result, the FCA held that "non-status Indians as a group do not lend themselves to the declaration of general application sought by the respondents." ${ }^{2}$ Given that there is no benefit to considering the issue in a general manner, the declaration "is redundant and lacks practical utility." ${ }^{3}$

\section{(2) The Métis}

The FCA held that the declaration has practical utility for the Métis. A contrary conclusion could not be found in light of the findings by Justice Phelan that "absence of jurisdictional certainty has led to disputes between the federal and provincial governments that have resulted in the Metis being deprived of many necessary programs and resources"; ${ }^{54}$ as well, although the federal government "largely accepted jurisdiction over the Metis until

46 Daniels, supra note 1 at para. 75.

47 Indian Act, RSC 1985, c I-5.

48 Daniels, supra note 1 at para. 76.

49 Reference whether "Indians" includes "Eskimo" [1939] SCR 104.

50 Daniels, supra note 1 at para. 78.

51 Ibid. at para. 77.

52 Ibid. at para. 79.

53 Ibid. at para. 76.

54 Ibid. at para. 71. 
the mid-1980s," it no longer exercises its jurisdiction or spending power on their behalf. ${ }^{55}$ Also at issue was the refusal of the "federal government to negotiate or enter treaties with respect to unextinguished Aboriginal rights, or agreements on other Aboriginal matters or interests analogous to those treaties and agreements" made with First Nations - a position maintained by the federal government because of an absence of higher court authority, as was recommended by the 1996 Royal Commission on Aboriginal peoples. ${ }^{56}$ Another important finding of fact was that the federal government acknowledged in its own documents that:

The Métis and non-status Indian people, lacking even the protection of the Department of Indian Affairs and Northern Development, are far more exposed to discrimination and other social disabilities. It is true to say that in the absence of Federal initiative in this field they are the most disadvantaged of all Canadian citizens. ${ }^{57}$

Viewed in isolation, the practical utility of the declaration in Daniels may be limited to its potential political force to pressure government into action; however, such force can be significant. For example, a declaration in Calder in 1973 that Aboriginal title exists in Canada resulted in the federal government initiating the comprehensive land claim and modern treaty negotiation processes. ${ }^{58}$ Other potential consequences become more apparent when Daniels is read together with decisions of the SCC on Métis constitutional rights. In this wider legal context, one can argue that a declaration has significant practical utility because it (1) would remove a constitutional excuse used by federal and provincial governments to avoid negotiating Métis Aboriginal rights and socioeconomic needs; (2) would strengthen arguments to compel federal consultation and good-faith negotiation on unfulfilled constitutional obligations and other solemn promises to Métis; and (3) may support legal arguments to extend programs and services to Métis.

Here, $M M F$ is of particular relevance in terms of what it says about fiduciary obligations and the honour of the Crown. It supports drawing a distinction between the existence of a fiduciary relationship and the duties derived therefrom; however, it also creates a constitutional duty derived from the honour of the Crown to act with diligence in purposeful fulfillment of constitutional provisions and solemn promises aimed at reconciliation of Aboriginal interests. Although honour of the Crown exists as a common law and constitutional principle, ${ }^{59}$ it operates much like equity in some respects and procedural fairness in others, generating substantive and procedural obligations to fulfill

55 Ibid. at para. 70.

56 Ibid. at para. 72.

57 Daniels FC, supra note 15 at para. 26.

58 Calder et al v Attorney-General of British Columbia [1973] SCR 313.

59 Beckman v. Little Salmon/Carmacks First Nation, [2010] 3 SCR 103 at paras. 42, 62. 
Crown promises based on reasonable and legitimate expectations where it seems "just" to do so in the broader context of Aboriginal-Crown relations. Engagement of the honour principle and this duty may be a way to bring the federal government to the negotiation table, as anticipated by the FCA in Daniels when it comments on the relationship between the practical utility of the declaration and federal refusal to negotiate with the Métis absent a ruling on jurisdiction. ${ }^{60}$ The combined message of Daniels and $M M F$ is that Métis are Aboriginal peoples, under federal jurisdiction, with similar constitutional rights as other Aboriginal peoples, and with whom reconciliation is to be negotiated. I speak first to key points in $M M F$ and then bring the discussion back to the potential practical consequences of the declaration Daniels.

$M M F$ concerned the interpretation of s. 31 of the Manitoba Act, $1870 .{ }^{61}$ The purpose of the Manitoba Act was to bring Manitoba peaceably into confederation and address the concerns of Métis and other settlers in possession of Manitoba lands. ${ }^{62}$ The Métis negotiated, as part of the creation of the province, the allocation of 1.4 million acres of land to Métis children as well as land grants to Métis and other settlers in possession of land through a separate series of land grants. The promise to the children was subsequently included in s. 31 of the Manitoba Act, and the promise to Métis and other settlers in s. 32. However, errors and delays in implementing these sections, along with underestimation of eligible recipients, insufficient legislative response, instances of federal facilitation of land scrip speculation, and other frauds and abuses resulted in many Métis not receiving the land grants promised.

The Manitoba Métis Federation (the Federation) sought three declarations for the purpose of bringing federal and provincial governments to the negotiation table. These were: (1) the federal government breached its fiduciary duty in implementing sections 31 and 32 of the Manitoba Act; (2) the federal government failed to implement these sections in a manner consistent with the honour of the Crown; and (3) certain legislation enacted to implement these provisions was outside the jurisdiction of the province of Manitoba. ${ }^{63}$ In determining whether to grant the declarations, the SCC addressed two main issues: (1) whether Canada failed to act in accordance with its legal obligation, and (2) whether the claim was barred by the doctrine of laches or by limitations law. ${ }^{64}$

On the first issue, the SCC agreed with the Courts below that the claim based on s. 32 was not established, and therefore it was not necessary to determine the constitutionality of the implementing legislation. They also held that

60 Daniels, supra note 1.

61 Manitoba Act, 1870, supra note 19.

62 Ibid.

$63 M M F$, supra note 4 at para. 7.

64 Ibid. at para. 8 . 
s. 31 of the Manitoba Act constitutes a constitutional obligation to the Métis people of Manitoba, an Aboriginal people, to provide the Métis children with allotments of land. The immediate purpose of the obligation was to give the Métis children a head start over the expected influx of settlers from the east. Its broader purpose was to reconcile the Métis' Aboriginal interests in the Manitoba territory with the assertion of Crown sovereignty over the area that was to become the province of Manitoba. The obligation enshrined in s. 31 of the Manitoba Act did not impose a fiduciary or trust duty on the government. However, as a solemn constitutional obligation to the Métis people of Manitoba aimed at reconciling their Aboriginal interests with sovereignty, it engaged the honour of the Crown. This required the government to act with diligence in pursuit of the fulfillment of the promise. On the findings of the trial judge, the Crown failed to do so and the obligation to the Métis children remained largely unfulfilled. ${ }^{65}$

The SCC also held that the relationship between the Métis and the Crown is fiduciary in nature, but not all dealings among parties in a fiduciary relationship give rise to fiduciary obligations. ${ }^{66}$ Fiduciary duties arise (1) where the Crown assumes discretionary control over specific cognizable Aboriginal interests, ${ }^{67}$ and (2) where there is an undertaking by an "alleged fiduciary to act in the best interests of the alleged beneficiary", a "defined person or class of persons vulnerable to a fiduciary's control" and "a legal or substantial practical interest of the beneficiary ... that stands to be adversely affected by the alleged fiduciary's exercise of discretion or control." ${ }^{68}$ For the first source of duty, "[t]he interest (title or some other interest) must be distinctly Aboriginal," which the SCC defines as "a communal Aboriginal interest in land that is integral to the nature of the Métis distinctive community and their relationship with the land." ${ }^{69}$ For the second source, the undertaking by the Crown must be one of "loyalty to act in the beneficiaries' best interests" by forsaking "the interests of all others in favour of those of the beneficiary, in relation to the specific interest at stake." ${ }^{\prime 0}$ Where Aboriginal title is alleged to ground a fiduciary obligation, Aboriginal title cannot be established by treaty or statute alone. ${ }^{71}$

The SCC concluded that s. 31 is not a source of federal fiduciary because " $[w]$ hile s. 31 shows an intention to benefit the Métis children, it does not demonstrate an

65 Ibid. at para. 9.

66 Daniels FC, supra note 15 at paras. 604-607.

67 Ibid. at para. 605, citing Wewaykum Indian Band v Canada 2002 SCC 79 at para. 79, [2002] 4 SCR 245.

68 MMF, supra note 4 at paras. 50, 60, citing Alberta v Elder Advocates of Alberta Society, 2011 SCC 24 at para. 36, [2011] 2 SCR 261[Elder].

$69 M M F$, ibid. at para. 53.

70 Ibid. at para. 61, citing Elder at para. 31.

$71 M M F$, ibid. at para. 58. 
undertaking to act in their best interests, in priority to other legitimate concerns, such as ensuring land was available for the construction of the railway and opening Manitoba for broader settlement." ${ }^{\prime 2}$ Further, the alleged Crown that the practice of dealing with Métis as an Aboriginal people at the time was insufficient to establish "that the Métis held either Aboriginal title or some other Aboriginal interest in specific lands as a group,"73 giving rise to a fiduciary obligation. The SCC also held that there was no fiduciary obligation sourced in a "cognizable Aboriginal interest." The Federation argued that the historical Crown practice of accepting that any organized Aboriginal group had title in some form, and that the words "toward extinguishment of Indian title" in s. 31, were conclusive proof of preexisting Aboriginal title - not title granted or created by Parliament. The SCC disagreed, ${ }^{74}$ and also said that the finding at trial that "Métis had no communal Aboriginal interest in land" was fatal to this contention. ${ }^{75}$

Although beyond the scope of this comment, it is important to note that if $M M F$ is interpreted to restrict the foundation of federal fiduciary obligations to Aboriginal interests in land recognized at common law, this is a narrower understanding than the case law upon which it relies. ${ }^{76}$ The reasoning of the SCC is also problematic in assuming Métis Aboriginal title cannot have individual ownership components and must be consistent with judicial understandings of communal First Nation title. The content of Métis Aboriginal title should be determined by the nature, Indigenous laws, and landholding patterns integral to the distinct culture of a Métis people at the date of effective European control. ${ }^{77}$

In Daniels, Justice Phelan held that a fiduciary relationship is affirmed through Métis inclusion in s. 91(24). Does this mean that there is a corresponding fiduciary obligation to negotiate or provide the same programs and services to Métis as to status Indians? Justice Phelan said no in Daniels, and $M M F$ supports this conclusion. There is no global fiduciary obligation that arises by virtue of inclusion in s. 91(24) or affirmation of Métis in the Crown-Aboriginal fiduciary relationship. This is where the constitutional principles of reconciliation, honour of the Crown, and equality become important.

Despite its ruling on fiduciary duty, the SCC emphasized in MMF that the Métis were historically engaged in national processes of reconciliation, and should continue to be. Section 31 is characterized as part of that process - a product of negotiation that formed part of a "larger set of negotiations on the terms on which Manitoba would enter Canada as

72 Ibid. at para. 62.

73 Ibid. at para. 58.

74 Ibid. at paras. 57-58.

75 Ibid. at para. 59.

76 See e.g. Nunavut Tungavik Incorporated v Canada (Attorney General) 2014 NUCA 02 April 24 at paras. 195-203, Hunt J, dissenting.

77 Delgamuukw v British Columbia, [1997] 3 SCR 1010, [1997] SCJ No 108 at para 147[Delgamuukw]; O’Toole, supra note 20 at 184-187. 
a province."78 This process engaged a Crown "duty of diligent, purposive fulfillment."79 The SCC drew an analogy between such negotiated promises and treaty, in that they "are arrived at after a course of consultation" for the "overarching purpose of reconciling Aboriginal interests with the Crown's sovereignty," and in that a "certain measure of solemnity" and "intention to create obligations" attaches to both. ${ }^{80}$ When the issue is implementation of a constitutionalized obligation, the "honour of the Crown requires that the Crown: (1) takes a broad purposive interpretation of the promise; and (2) acts diligently to fulfill it." 11

Honour of the Crown "refers to the principle that servants of the Crown must conduct themselves with honour when acting on behalf of the sovereign." ${ }^{2}$ It is not just "a mere incantation, but rather a core precept that finds its application in concrete practices" and gives rise to different duties in different circumstances." ${ }^{33}$ It is "not a cause of action itself; rather it speaks to how obligations that attract it must be fulfilled." ${ }^{4}$ The ultimate purpose of honour of the Crown is linked to the purpose and process of reconciliation. It recognizes the impact of the "superimposition of European laws and customs" on Aboriginal societies, including the Métis, who "were here first," "were never conquered," and yet "became subject to a legal system that they did not share." ${ }^{85}$ Obligations arising from honour vary, depending on context, but in all cases, they are owed to an Aboriginal group. ${ }^{86}$

The duty of diligent, purposeful fulfillment applies to all solemn promises aimed at reconciliation of Aboriginal interests. It is not dependent upon the constitutional nature of the instrument, but upon the Crown's special relationship with Aboriginal peoples and the equitable assumption that it intends to fulfill its obligations. Not every act of negligence or mistake in implementation will give rise to a breach of duty and declaration that brings dishonour to the Crown, nor does "honour of the Crown constitute a guarantee that the purpose of the promise will be achieved, as circumstances and events may prevent fulfillment, despite the Crown's diligent efforts." 87 What is required for a finding that the Crown acted contrary to what honour requires is "a persistent pattern of errors and

$78 M M F$, supra note 4 at para. 30 .

79 Ibid. at para. 94.

80 Ibid. at para. 71.

81 Ibid. at para. 75 .

82 Ibid. at para. 65.

83 Haida Nation v. British Columbia (Minister of Forests), 2004 SCC 73 at paras. 16, 18, [2004] 3 S.C.R. 511 [Haida].

$84 M M F$, supra note 4 at para. 73.

85 Ibid. at para. 67.

86 Ibid. at para. 72 .

87 Ibid. at para. 82 . 
indifference that substantially frustrates the purposes of the solemn promise" 88 and an absence of "satisfactory explanation." ${ }^{9}$ Applying these principles to s. 31 of the Manitoba Act, the SCC held the following in MMF:

The Métis were promised implementation of the s. 31 land grants in "the most effectual and equitable manner." Instead, the implementation was ineffectual and inequitable. This was not a matter of occasional negligence, but of repeated mistakes and inaction that persisted for more than a decade. A government sincerely intent on fulfilling the duty that its honour demanded could and should have done better. ${ }^{90}$

Read together with Daniels, the reasoning in $M M F$ bolsters arguments for a federal duty to negotiate Métis Aboriginal rights and socioeconomic needs. This can be argued in a number of ways. One argument is sourced in the promise of Prime Minister Trudeau to negotiate the identification and definition of the rights to be included in s. 35 of the Constitution Act, 1982, and the failure of the s. 37 First Minister's Conferences to reach this goal. A persistent pattern of indifference and refusal to negotiate frustrates both the purposes of s. 91(24) constitutional jurisdiction being vested in the federal Crown and the promise of s. 35 to reconcile Aboriginal interests with the imposition of Crown sovereignty. Obligations to Métis dating back to 1867 remain unfulfilled, and uncertainty of jurisdiction is not a satisfactory explanation. Other arguments supporting a justiciable duty to negotiate flowing from these circumstances include statements by the SCC about the need to negotiate Métis rights clarification, ${ }^{91}$ and the duty to engage in negotiations concerning Aboriginal land interests in good faith, as honour requires. ${ }^{92}$ But does honour of the Crown mean the federal government must provide the same level of programs and services to all Aboriginal peoples under its constitutional jurisdiction?

Inclusion of Métis under s. 91(24) strengthens Métis claims to programs and services aimed at Aboriginal rights or at socioeconomic consequences arising from denial of Aboriginal rights, but does not guarantee equal access. However, MMF and Daniels make it clear that Métis are similarly situated to Inuit and First Nations under federal jurisdiction and in the national process of reconciliation. Section 15 equality principles suggest that they should be treated in similar ways - for example, by including Métis in federal comprehensive

88 Ibid.

89 Ibid. at para. 108.

90 Ibid. at para. 128.

91 See e.g. Powley, supra note 17.

92 Delgamuukw, supra note 77 at para. 168; Haida, supra note 83 at para. 45; see also Nigel Bankes, "The Manitoba Métis Case and Honour of the Crown," The University of Calgary Faculty of Law Blog on Developments in Alberta Law (blog), April 9, 2013, http://ablawg.ca/2013/04/09/the-manitoba-metis-caseand-the-honour-of-the-crown/. 
and specific land-claims resolution processes. ${ }^{93}$ Findings of fact in Daniels that Métis are among the most discriminated against and disadvantaged Canadian citizens also support the creation of programs and legislation aimed at ameliorating socioeconomic hardship analogous to those measures extended to status Indians and Inuit. This is consistent with the recent ruling of the SCC in Cunningham, in which membership provisions of Métis settlement legislation withstood s. 15 challenges given the "goal of establishing a Métis land base to preserve and enhance Métis identity, culture and self-governance, as distinct from surrounding Indian cultures and from other cultures in the province." ${ }^{4}$ The combined message of MMF, Daniels, and Cunningham is that Métis are Aboriginal peoples, under federal jurisdiction, with similar constitutional rights to survival of their distinct cultures, and with whom reconciliation is to be negotiated.

Issues of Definition, Interpretation, and Provincial Powers

Daniels has no effect on how Métis are defined for the purpose of exercising s. 35 constitutional rights, or how Métis people define themselves. It also does not say that Métis are culturally Indians. It does say that the term "Indian" as it was used in 1867 and in s. 91(24) is broad enough to include Métis in the same way it includes Inuit. However, Justice Phelan's definition of Métis was challenged on appeal because of its emphasis on individual Indian ancestry and its alleged inconsistency with the definition and recognition of Métis as a distinct Aboriginal people in four decisions of the SCC: Powley, Blais, Cunningham, and $M M F$. The Métis National Council of Canada and the Métis Nation of Ontario intervened to argue that the result was right, but the reasoning on Métis identity was wrong. They argued that s. 91(24) is concerned with collectivities and is aimed at facilitating reconciliation of the assertion of sovereignty over peoples, not individuals. Further, the understanding of Métis as a distinct Aboriginal people must be read into the understanding of Métis in s. 91(24). ${ }^{95}$ The SCC defined Métis in Powley as "distinctive peoples who, in addition to their mixed ancestry, developed their own customs, way of life and recognizable group identity separate from their Indian or Inuit and European forbearers." ${ }^{\prime 96}$ Although Powley did not exhaustively define who is a Métis for all purposes, it rejected a definition that is based on mixed heritage and Aboriginal ancestry alone.

The FCA agreed that Justice Phelan's approach to defining Métis was problematic, and considered that it was open to at least three different interpretations, but that the one intended

93 Canadian Charter of Rights and Freedoms, Part 1 of the Constitution Act, 1982, being Schedule B to the Canada Act 1982 (UK), 1982, c 11.

94 See e.g. Cunningham, supra note 45 at para. 62 for a discussion of the ameliorative purpose of the Métis settlement legislation in Alberta and why it does not violate s. 15 of the Charter of Rights and Freedoms, ibid.

95 Jean Teillet and Jason Madden, "Plainspeak on the Daniels Case," prepared for the Métis National Council, February 2013, http://www.metisnation.ca/wp-content/uploads/2013/02/Daniels-PlainspeakFINAL-REVISED.pdf.

96 Powley, supra note 17 at para. 87. 
was consistent with history and the rulings of the SCC. ${ }^{97}$ By defining Métis in terms of their Indian heritage, Justice Phelan may have meant that they are descended "from members of the 'Indian' race", that their heritage is the same as First Nations (a view contrary to history and the SCC), or that they share an "indigenousness or Aboriginal heritage." 98 The FCA accepted the submission by the Métis Nation of Ontario that a progressive interpretation of s. 91(24) requires that Métis mean more than people's "racial connection to their Indian ancestors." 99 It also held that "individual elements of the Constitution are linked to one another and must be interpreted by reference to the structure of the Constitution as a whole," therefore requiring the distinctiveness of Métis identity to inform an understanding of who the Métis are for the purpose of s. 91(24). ${ }^{100}$ However, aspects of Justice Phelan's reasoning convinced the FCA that he was not ignoring the SCC and equating Métis with First Nations identity; these aspects included the way in which he defined Métis and nonstatus separately before treating them together as a group, and used Powley to discuss the contours and contexts of Métis constitutional identity. ${ }^{101}$

The FCA also distinguished the Blais decision discussed earlier. The federal government argued that the distinctiveness of Métis means that they are not s. 91(24) Indians on three grounds: (1) the SCC expressly said that it was only concerned with interpreting s. 13 of the Manitoba NRTA, and was not determining whether the term "Indians" in s. 91(24) included the Metis; ${ }^{102}$ (2) the facts in Blais are completely different from those in Daniels, including the nature, historical context, and geographical scope of the constitutional instruments being interpreted; and (3) the objectives underlying s. 13 of the NRTA were different from s. 91(24), which was aimed at all native people by necessity "in order to facilitate development of the Dominion and pursue the federal government's plan to develop and settled lands in the North-Western Territory." 103

The federal government also argued that Justice Phelan erred in "his application of progressive statutory interpretation by failing to identify what changes require a new view" of who is included in s. 91(24) beyond those originally intended. ${ }^{104}$ The FCA disagreed and held that, in any event, findings of fact at trial demonstrated that a progressive interpretation was not necessary, as the intent at the time of Confederation in 1867 was to adopt a definition of Indians broad enough to include Métis. ${ }^{105}$

97 Daniels, supra note 1 at para. 88.

98 Ibid. at paras. $89-91$.

99 Ibid. at para. 96.

100 Ibid. at paras. 98, 99.

101 Ibid. at paras. 104, 107.

102 Ibid. at para. 116.

103 Ibid. at para. 120.

104 Ibid. at para. 127.

105 Ibid. at paras. 133-143. 
The appellants also argued that a declaration that Métis are within s. 91(24) federal jurisdiction will leave provincial legislation, such as Alberta's Metis Settlements Act (MSA), open to challenge because of a doctrine in constitutional law known as interjurisdictional immunity. It is for this reason that the government of Alberta intervened in the appeal, seeking to have the declaration overturned. The idea is that s. 91(24) shields Aboriginal people from provincial laws that go to "the core of Indianness", including Indian status and Aboriginal rights. ${ }^{106}$ As a result, the province cannot pass laws that single out Aboriginal people for special treatment (e.g., provincial "Indian Education Act") or general laws that impair their "Indianness", including Aboriginal rights (e.g., hunting laws). The only circumstances under which provinces can pass laws of general application that affect "Indianness" are when such laws have either been referentially incorporated as federal legislation through s. 88 of the Indian Act, or when such laws intersect with the province's constitutional powers over Indian hunting, fishing, and trapping on unoccupied Crown land under the Natural Resource Transfer Agreements.

Dale Gibson argues that the proper way to understand this idea of core federal jurisdiction as it applies to Métis is a concept of "Métisness" - that which is "vital, essential or integral" to the distinctive identity and cultural survival of Métis people. ${ }^{107}$ A law that singles out Métis, that is in pith and substance (objective purpose) about Métis as an Aboriginal people or their Aboriginal rights, may fall outside provincial legislative jurisdiction. Provincial laws of general application that affect Métis Aboriginal rights may also be constitutionally uncertain to the extent that they apply to Métis. Section 88 of the Indian Act is only concerned with status Indians and reserve land, so does not apply to Métis. Similarly, Blais found that the Manitoba NRTA does not include the Manitoba Métis. The result may be that there is no jurisdictional foundation for a provincial government to pass laws of general application that impair Métis Aboriginal rights. ${ }^{108}$ The contrary argument is that "impair" means "terminate." The provinces cannot terminate Aboriginal rights, but can pass laws that affect and regulate Aboriginal rights as long as the federal government has not already done so. ${ }^{109}$

On this issue, the FCA in Daniels states: "In Reference re Employment Insurance Act (Canada), the Supreme Court observed that the power of one level of government to legislate in relation to one aspect of a matter takes nothing away from the power of the other level to control another aspect within its own jurisdiction. ... [T] his is a complete answer to the appellants' argument." 110 But is it?

106 Delagamuukw, supra note 77 at para. 178.

107 D. Gibson, “Métis Interjurisdictional Immunity: A Third Way to Protect Métis Constitutional Rights?," in Métis-Crown Relations, eds. F. Wilson and M. Mallet (Toronto: Irwin Law Inc., 2008), 201.

108 See C. Bell and C. Leonard, "A New Era in Métis Constitutional Rights: The Importance of Powley and Blais," Alberta Law Review 41, no. 4 (2004), 1049.

109 PM McAdam, “Interjurisdictional Immunity and Métis Aboriginal Rights: A Provincial Perspective”, in Métis-Crown Relations, eds. F. Wilson and M. Mallet (Toronto: Irwin Law Inc., 2008), 269.

110 Ibid. at para. 150. 
Even if the FCA is overturned on this issue, there are many ways to argue that legislation such as Alberta's Metis Settlements Act (MSA) is constitutionally valid. One is that recent decisions of the SCC call for a "restrained approach" in the application of the doctrine of interjurisdictional immunity in favour of the doctrine of paramountcy - as long as the federal government is not occupying the field, the provinces can. ${ }^{111}$ Another is that provincially legislated ameliorative programs that benefit Aboriginal people are permitted. In Daniels, Justice Phelan says Cunningham is relevant on this point because the SCC found the Métis settlements regime ameliorative. ${ }^{112}$ However, constitutional scholars disagree on whether these doctrines apply to laws that are aimed at Métis as a people or Métis Aboriginal rights. ${ }^{113}$ Regardless, provincial legislation implementing negotiated agreements may also attract the duty of diligent, purposeful fulfillment. For example, Alberta's Métis settlement legislation is derived from negotiations and is protected in the Constitution of Alberta. Inclusion of Métis under s. 91(24) could mean that the provincial and federal governments have a duty to do what is necessary to uphold these obligations, such as enacting parallel implementing legislation.

\section{Conclusion}

Honour of the Crown and the fiduciary relationship inform s. 91(24), but it is not necessary for Métis or non-status people to fall within s. 91(24) for the constitutional principle of honour to apply. Honour calls on both federal and provincial governments to enter into good faith negotiations on unfulfilled constitutional obligations and other solemn promises to Métis people. Regardless of which government has legislative jurisdiction, both the federal and provincial governments can use spending powers and other heads of jurisdiction to participate meaningfully in negotiations in ways that benefit Métis. However, Daniels clarifies who has jurisdiction to implement agreements through legislation directed at Métis, removes a constitutional excuse used by federal and provincial governments to avoid negotiating Métis Aboriginal rights and the socioeconomic needs of non-status Indians, and supports legal arguments to extend more programs and services based on the fiduciary relationship, honour of the Crown, and equality principles.

111 McAdam, supra note 109.

112 Daniels FC, supra note 15 at paras. 596-597.

113 See e.g. K. McNeil, "The Métis and the Doctrine of Interjurisdictional Immunity: A Commentary," in Métis-Crown Relations, eds. F. Wilson and M. Mallet (Toronto: Irwin Law Inc., 2008), 315. 